\title{
Effect of Pulmonary Rehabilitation on Patients With Severe and Very Severe COPD and Emphysema
}

\author{
Amfizem Baskın Ağır ve Çok Ağır KOAH Hastalarında Pulmoner \\ Rehabilitasyonun Etkisi
}

\author{
(D) Cantürk Taşçı, (1) Deniz Doğan Mülazimoğlu, (1) Deniz Doğan, (1) Nesrin Öcal, (1) Yakup Arslan \\ University of Health Sciences Turkey, Gülhane Training and Research Hospital, Clinic of Chest Diseases, Ankara, Turkey
}

\begin{abstract}
Objective: Chronic obstructive pulmonary disease (COPD) is one of the significant causes of death worldwide. Exercise-induced dyspnea is a common symptom among patients with emphysema dominant-COPD. Decreased exercise capacity and dyspnea are the basis of morbidity of the disease. Pulmonary rehabilitation (PR) is an effective therapy for patients with COPD. Evidence shows, PR improves exercise capacity and the course of the disease.

Methods: Fifty-eight patients with severe and very severe COPD in an 8 week-PR program were evaluated retrospectively. Change in spirometric measurements, 6-minute walking test (6-MWT) results, and modified Medical Research Council (mMRC) dyspnea scores were compared pre and post PR.

Results: Thirty-four of fifty-eight patients have met the inclusion criteria. Pre- and post-PR measurements of percent predicted forced vital capacity (FVC) were $76.7 \pm 4.6$ vs. $77.4 \pm 4.6(p=0.207)$; FEV1 were $33.2 \pm 7.1$ vs. $37.5 \pm 7.6(p<0.001)$ and FEV1/FVC were $43.1 \pm 9.7$ vs. $48.2 \pm 10.7$ $(p<0.001)$. Distance on 6-MWT were $254.9 \pm 77.6 \mathrm{~m}$ vs. $328.1 \pm 93.3 \mathrm{~m}(p<0.001) ; \mathrm{mMRC}$ dyspnea scores were $3.14 \pm 0.74 \mathrm{vs} .2 .26 \pm 0.66(p<0.001)$ pre- and post-PR.

Conclusion: PR is an underrated yet very effective therapy for patients with COPD. Instead, of drug-only treatment models, PR is an essential option for the management of COPD. The PR effect on respiratory function and exercise capacity can be more apparent with a more extensive study population.
\end{abstract}

Keywords: COPD, emphysema, rehabilitation, pulmonary rehabilitation, spirometry

\section{öz}

Amaç: Kronik obstrüktif akciğer hastalığı $(\mathrm{KOAH})$, tüm dünyada en önemli ölüm nedenleri arasında yer almaktadır. Özellikle amfizem baskın KOAH hastalarında en önemli semptom egzersiz dispnesidir. Hastalığın temelinde yatan patoloji ile birlikte düşünüldüğünde bu semptom en önemli mortalite nedenleri arasinda yer almaktadır. Pulmoner rehabilitasyon (PR) KOAH hastalarında başta egzersiz dispnesi üzerine olumlu etkileri ile birlikte hastalığın seyri üzerine olumlu bir tedavi yöntemidir.

Gereç ve Yöntem: Bu çalışmada, çalışma kriterlerine uygun toplam 58 ağır ve çok ağır KOAH hastasının dosya verileri geriye dönük olarak değerlendirildi. Ortalama sekiz hafta süren PR programı öncesi ve sonrasında hastaların spirometrik verileri, altı dakikalik yürüme mesafeleri, modifiye Medikal Araştırma Kurulu (mMRC) puanları kaydedildi ve istatistiksel olarak karşılaştırıldı.

Bulgular: Hastaların PR öncesi ve sonrası FEV1 değerleri, sırası ile beklenenin \%33,2 $\pm 7,1$ 'e karşılık \%37,5 $\pm 7,6$ ( $p<0,001)$. FEV1/FVC değerleri $43,1 \pm 9,7^{\prime}$ e karşılık 48,2 $\pm 10,7$ ( $p<0,001$ ), mMRC puanları 3.14 \pm 0.74 'e karşılık 2.26 \pm 0.66 ( $p<0.001$ ), 6-dakika yürüme mesafeleri 254,9 977,6

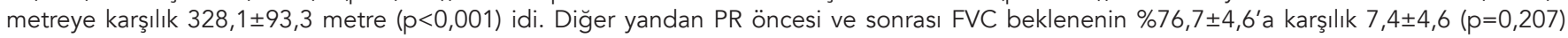
olarak bulundu.

Sonuç: KOAH hastalarının takip ve tedavisinde PR programları çoğu zaman gözden kaçmakta ve hastalar bu tedavi yöntemlerinden uzak kalmaktadır. Farkındalığın artıııması ile sadece ilaç tedavisinin $\mathrm{KOAH}$ li hasta yönetiminde yeterli olmadığının gösterildiği çalışmamızda, olgu sayılarının da arttııldı̆̆ı çalışmalar ile PR etkinliği daha da belirgin bir şekilde gösterilecektir.

Anahtar Kelimeler: $\mathrm{KOAH}$, amfizem, rehabilitasyon, pulmoner rehabilitasyon, spirometri

Address for Correspondence: Deniz Doğan Mülazimoğlu, University of Health Sciences Turkey, Gülhane Training and Research Hospital, Clinic of Chest Diseases, Ankara, Turkey

Phone: +90 5057499080 E-mail: denizdoganmulazim@gmail.com ORCID ID: orcid.org/0000-0001-6254-0369

Cite as: Taşçı C, Doğan Mülazimoğlu D, Doğan D, Öcal N, Arslan Y. Effect of Pulmonary Rehabilitation on Patients With Severe and Very Severe COPD and Emphysema. Med J Bakırköy 2021;17:121-129

Received: 22.08 .2020

Accepted: 16.06 .2021 


\section{INTRODUCTION}

Chronic obstructive pulmonary disease (COPD) is the third major cause of death worldwide, characterized by airflow limitation, persistent respiratory symptoms, and high morbidity (1). Acute exacerbations of COPD and hospitalizations are observed frequently as the disease severity increases. Exercise-induced dyspnea is a common symptom among patients with COPD and emphysema. Loss of elasticity in the lungs is the primary cause of dyspnea on emphysema. Due to the early closing in small airways on expiration, air trapping occurs, and consequently, inspiratory capacity decreases. Decreased inspiratory capacity is the spirometric manifestation of reduced exercise capacity. Intrathoracic pressure rises with the increased air trapping, so cardiac functions are affected negatively, and mortality increases. Despite the medication, exercise intolerance is the least improvable symptom in patients with emphysema. Pulmonary rehabilitation (PR) is a multidisciplinary approach for improving exercise capacity and quality of life. With the help of a PR program, exercise tolerance, daily physical activity, self confidence can improve, while anxiety and depression diminish. Due to such alterations, healthcare costs can be reduced $(2,3)$. In this study, the effectiveness of PR on patients with COPD and emphysema is investigated.

\section{METHODS}

This retrospective, cross-sectional, analytical study was performed between January 01, 2017 and December 31, 2019. This study was conducted following the amended Declaration of Helsinki. The parameters were recorded after obtaining Gülhane Research and Training Hospital's noninterventional ethics board approval.

Fifty-eight patients with severe and very severe emphysema dominant-COPD were referred to the PR program by the outpatient clinic. All of them had been using long-term oxygen therapy. It is planned 3 times a week for 8-week duration. The exclusion criteria were inability to complete the 8 week-PR program, suspicion of infection by the referral time, acute coronary syndrome, congestive heart failure (ejection fraction $<40 \%$ ), cardiac or thoracic surgery within the 3 months by referral time. After these exclusion criteria, 34 patients were included in the analysis for this study (Table 1). Pre and post-PR spirometric measurements, modified Medical Research Council (mMRC) dyspnea scores, and 6-minute walking test (6-MWT) results were recorded.

\section{Statistical Analysis}

R software was used for the statistical analysis. Variables were analyzed with the Kolmogorov-Smirnov test to evaluate the distribution. Results for descriptive statistics are expressed as mean \pm standard deviation. Continuous variables of pre and post-PR change were analyzed with paired t-test or Wilcoxon Signed-rank test. Statistical significance was accepted as $p<0.05$.

\section{RESULTS}

Fifty-eight patients with severe and very severe emphysema dominant COPD attended the PR program in Pulmonary Rehabilitation Unite of Pulmonary Diseases Clinic from January 01, 2017 to December 31, 2019. For this study, the patient files were examined. 34 patients have met the inclusion criteria (Figure 1). Mean age was $63.4 \pm 3.5$ years of all study population, it was $64.6 \pm 3.2$ years for men and $63.3 \pm 3.6$ years for women. Only 3 of 34 patients were women. All spirometric parameters except forced vital capacity (FVC) were improved significantly after PR. In addition, a significant increase in MMRC dyspnea scores and distance of 6-MWT were noted. The results of the study are summarized in Table 1.

\section{DISCUSSION}

This study shows patients with emphysema dominant-COPD benefit from PR. Respiratory function test parameters, exercise capacity, and dyspnea improve significantly with PR.

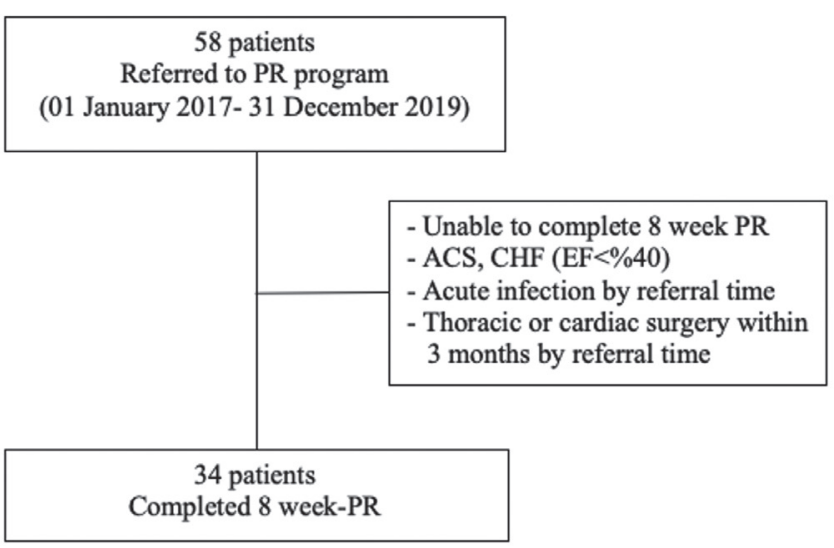

Figure 1. Study flow diagram

Definiton of abbreviations: PR: Pulmonary rehabilitation, ACS: Acute coronary syndrome, CHF: Congestive heart failure, EF: Ejection fraction

The major goal of COPD treatment is diminishing symptoms and increasing quality of life. Many patients with COPD have a limitation of activity due to dyspnea. PR is an essential treatment option for this group of patients. Physiotherapy reduces work of breathing and oxygen consumption, thus 


\begin{tabular}{|c|c|c|c|}
\hline Variable & & Value \pm SD & $p$ \\
\hline Age, years & & $63.4 \pm 3.5$ & - \\
\hline \multirow{3}{*}{ FEV1, \% predicted } & Pre-PR & $33.2 \pm 7.1$ & \multirow{3}{*}{$<0.001$} \\
\hline & Post-PR & $37.5 \pm 7.6$ & \\
\hline & Difference & $4.3 \pm 4.2$ & \\
\hline \multirow{3}{*}{ FVC, \% predicted } & Pre-PR & $76.7 \pm 4.6$ & \multirow{3}{*}{0.207} \\
\hline & Post-PR & $77.4 \pm 4.6$ & \\
\hline & Difference & $0.61 \pm 2.8$ & \\
\hline \multirow{3}{*}{ FEV1/FVC } & Pre-PR & $43.1 \pm 9.7$ & \multirow{3}{*}{$<0.001$} \\
\hline & Post-PR & $48.2 \pm 10.7$ & \\
\hline & Difference & $5.2 \pm 5.7$ & \\
\hline \multirow{3}{*}{ FEF25-75, \% predicted } & Pre-PR & $40.7 \pm 5.9$ & \multirow{3}{*}{0.002} \\
\hline & Post-PR & $43.6 \pm 7.1$ & \\
\hline & Difference & $2.9 \pm 5.1$ & \\
\hline \multirow{3}{*}{ PEF, \% predicted } & Pre-PR & $54.3 \pm 8.5$ & \multirow{3}{*}{$<0.001$} \\
\hline & Post-PR & $61.0 \pm 7.4$ & \\
\hline & Difference & $6.7 \pm 4$ & \\
\hline \multirow{3}{*}{ mMRC score* } & Pre-PR & $3.14 \pm 0.74$ & \multirow{3}{*}{$<0.001$} \\
\hline & Post-PR & $2.26 \pm 0.66$ & \\
\hline & Difference & $-0.88 \pm 0.68$ & \\
\hline \multirow{3}{*}{$\begin{array}{l}\text { 6-minute-walk distance, } \\
\mathrm{m}\end{array}$} & Pre-PR & $254.9 \pm 77.6$ & \multirow{3}{*}{$<0.001$} \\
\hline & Post-PR & $328.1 \pm 93.3$ & \\
\hline & Difference & $73.2 \pm 63.4$ & \\
\hline
\end{tabular}

SD: Standard deviation, FEV1: Forced expiratory volume in one second, FVC: Forced vital capacity, PR: Pulmonary rehabilitation, mMRC: Modified medical research council

${ }^{*} \mathrm{mMRC}$ dyspnea score scale ranges from 0 to 4 , with higher scores indicating more severe dyspnea

diminishes dyspnea. Many studies use PR for lung cancer, idiopathic pulmonary fibrosis, and chronic respiratory diseases (4). However, unfortunately, many patients do not have access to $P R$.

Thirty-four patients constitute this study population, completed the 3 times a week, 8 week-PR programs. Pre-PR predicted \% FEV1 mean was 33.2 \pm 7.1 . Lower FEV1 means lower exercise capacity and quality of life for patients with COPD. Post-PR predicted \% FEV1 mean rose to $37.5 \pm 7.6$ in this study. Although it may be seen as a slight increase, this change of FEV1 increases exercises capacity. It can be understood from the increased distance of 6-MWT pre and post PR. This statistically significant change in predicted FEV1\% was + 4.3. Notably, three major PR studies show no significant increase in FEV1 \% pre and post PR (5-7).
The 6MWT is a safe, inexpensive, widely used tool to assess the functional status of patients with COPD. The difference in 6MWT is $54 \mathrm{mt}$ for patients with COPD to notice an improvement (8). In this study $\triangle 6 \mathrm{MWT}$ was $73.2 \pm 63.4 \mathrm{~m}$, substantially higher than the threshold.

Our study population distinguishes this study from others. Only patients with severe and very severe emphysema dominant-COPD were included in this study. In patients with chronic bronchitis dominant-COPD, it is not expected that significant improvement on overserved spirometric parameters. Pre-PR mean mMRC dyspnea score was $3.14 \pm 0.74$, post-PR, it declined to $2.26 \pm 0.66$. This shows that PR improves not only spirometric measurements also the sense of dyspnea. Although decreasing dyspnea and increasing exercise capacity with PR can be associated with life expectancy, the literature shows no clear connection (9). A study by Bowen et al. showed that after PR, 3-year life expectancy is $69 \%-85 \%$ for patients with COPD (10). Nevertheless, it is known that PR diminishes dyspnea in patients with COPD $(11,12)$.

PR program was planned for 8 weeks for patients with COPD in our daily practice. Only patients who completed 8 week-program have been included in the study. Based on the current literature, it is recommended to apply the PR program for at least 8 weeks, and for the optimum effect of the treatment, more than 8 weeks is required (13).

The study has some limitations. First, its retrospective methodology was a significant limitation. The study population was minimal, and there is no information about their comorbidities and pharmacological treatments. We believe that a prospective study with a large study population will overcome these limitations.

\section{CONCLUSION}

Our comprehensive, outpatient, 8 week-PR programs are effective for patients with severe and very severe COPD and emphysema component. Besides spirometric parameters, dyspnea scores and exercise capacity were all improved.

\section{ETHICS}

Ethics Committee Approval: Approval of the Local Research Ethics Committee of our tertiary hospital was obtained before initiating the study (University of Medical Sciences Turkey, Gülhane Training and Research Hospital, project no: 2020-13, date: 07.01.2020).

Informed Consent: Is a retrospective study.

Authorship Contributions: Surgical and Medical Practices: D.D., C.T., Y.A., Concept: D.D., C.T., N.Ö., Design: D.D., 
N.Ö., Data Collection or Processing: D.D.M., Y.A., Analysis or Interpretation: D.D., D.D.M., Y.A., Literature Search: D.D.M., C.T., N.Ö., Writing: D.D., D.D.M, C.T.

Conflict of Interest: No conflict of interest was declared by the authors.

Financial Disclosure: The authors declared that this study received no financial support.

\section{REFERENCES}

1. Singh D, Agusti A, Anzueto A, Barnes PJ, Bourbeau J, Celli BR, et al. Global Strategy for the Diagnosis, Management, and Prevention of Chronic Obstructive Lung Disease: the GOLD science committee report 2019. Eur Respir J 2019;53:1900164.

2. Neder JA, Arbex FF, Alencar MC, O'Donnell CD, Cory J, Webb KA, et al. Exercise ventilatory inefficiency in mild to end-stage COPD. Eur Respir J 2015;45:377-87.

3. American Thoracic Society/European Respiratory Society. ATS/ERS Statement on respiratory muscle testing. Am J Respir Crit Care Med 2002;166:518-624.

4. Prunera-Pardell MJ, Padín-López S, Domenech-Del Rio A, GodoyRamírez A. Effectiveness of a respiratory rehabilitation programme in patients with chronic obstructive pulmonary disease. Enferm Clin (Engl Ed) 2018;28:5-12.

5. Young P, Dewse M, Fergusson W, Kolbe J. Respiratory rehabilitation in chronic obstructive pulmonary disease: predictors of nonadherence. Eur Respir J 1999;13:855-9.

6. Selzler AM, Simmonds L, Rodgers WM, Wong EY, Stickland MK. Pulmonary rehabilitation in chronic obstructive pulmonary disease: predictors of program completion and success. COPD 2012;9:53845.

7. Fischer MJ, Scharloo M, Abbink JJ, van 't Hul AJ, van Ranst D, Rudolphus A, et al. Drop-out and attendance in pulmonary rehabilitation: the role of clinical and psychosocial variables. Respir Med 2009;103:1564-71.

8. Redelmeier DA, Bayoumi AM, Goldstein RS, Guyatt GH. Interpreting small differences in functional status: the Six Minute Walk test in chronic lung disease patients. Am J Respir Crit Care Med 1997;155:1278-82.

9. Li Y, Qian H, Yu K, Huang Y. Nonadherence in Home-Based Pulmonary Rehabilitation Program for COPD Patients. Can Respir J 2020;2020:5146765.

10. Bowen JB, Votto JJ, Thrall RS, Haggerty MC, Stockdale-Woolley R, Bandyopadhyay T, et al. Functional status and survival following pulmonary rehabilitation. Chest 2000;118:697-703.

11. Vogelmeier CF, Criner GJ, Martinez FJ, Anzueto A, Barnes PJ, Bourbeau J, et al. Global Strategy for the Diagnosis, Management, and Prevention of Chronic Obstructive Lung Disease 2017 Report. GOLD Executive Summary. Am J Respir Crit Care Med 2017;195:557-82.

12. Wilson AM, Browne P, Olive S, Clark A, Galey P, Dix E, et al. The effects of maintenance schedules following pulmonary rehabilitation in patients with chronic obstructive pulmonary disease: a randomised controlled trial. BMJ Open 2015;5:e005921.

13. Houben-Wilke $S$, Janssen DJA, Franssen FME, Vanfleteren LEGW, Wouters EFM, Spruit MA. Contribution of individual COPD assessment test (CAT) items to CAT total score and effects of pulmonary rehabilitation on CAT scores. Health Qual Life Outcomes 2018;16:205. 